\title{
Iron smelting in pre-colonial Zimbabwe: evidence for diachronic change from Swart Village and Baranda, northern Zimbabwe
}

ARTICLE in JOURNAL OF AFRICAN ARCHAEOLOGY · JUNE 2006

DOI: 10.3213/1612-1651-10062

CITATIONS

13

2 AUTHORS, INCLUDING:

Shadreck Chirikure

University of Cape Town

40 PUBLICATIONS 246 CITATIONS

SEE PROFILE
READS

31 


\section{Africa Magna Verlag}

Iron Smelting In Pre-Colonial Zimbabwe: Evidence for Diachronic Change from Swart Village and Baranda, Northern Zimbabwe Author(s): Shadreck Chirikure and Thilo Rehren

Source: Journal of African Archaeology, Vol. 4, No. 1 (2006), pp. 37-54

Published by: Africa Magna Verlag

Stable URL: http://www.jstor.org/stable/43135391

Accessed: 13-01-2016 08:00 UTC

Your use of the JSTOR archive indicates your acceptance of the Terms \& Conditions of Use, available at http://www.jstor.org/page/ info/about/policies/terms.jsp

JSTOR is a not-for-profit service that helps scholars, researchers, and students discover, use, and build upon a wide range of content in a trusted digital archive. We use information technology and tools to increase productivity and facilitate new forms of scholarship. For more information about JSTOR, please contact support@jstor.org. 


\title{
Iron Smelting In Pre-Colonial Zimbabwe: Evidence for Diachronic Change from Swart Village and Baranda, NORTHERN ZIMBABWE
}

\author{
Shadreck Chirikure \& Thilo Rehren
}

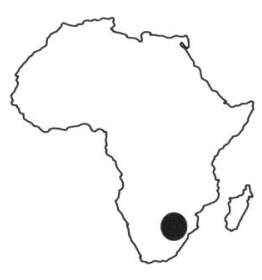

\begin{abstract}
In conventional reconstructions of southern African archaeology, the production of iron has been seen as unchanging for the last 2000 years. Significantly, this contrasts with the changes that have been noted in broader society and other classes of material culture of the same period. Despite iron being used as a chronostratigraphic indicator, virtually nothing is known on the patterns of iron production within the Iron Age and whether change in technology and the socio-cultural context of production took place. From a combined archaeological and metallurgical perspective, the historical development of iron working has never been explored. For example, it is not known whether similar types of furnaces were constantly operated throughout the last two millennia. Excavations at two sites in northern Zimbabwe, one GokomereZiwa (800 - 1200 cal AD) and one Zimbabwe tradition (1500 - $1700 \mathrm{cal} A D)$, have shown differences in iron pyrometallurgical debris, tentatively suggesting that they represent separate metal working practices. By comparing the archaeological and metallurgical evidence from the two sites, this paper represents an initial step in delineating patterns of indigenous iron production in one region of Zimbabwe.
\end{abstract}

\begin{abstract}
Résumé
Les reconstitutions archéologiques établies en Afrique $d u$ Sud considèrent que la production du fer est inchangée depuis 2000 ans. Ceci contraste de manière significative avec les changements observés dans des sociétés plus conséquentes et pour d'autres types de matériaux datant de la même période. En dépit du fait que le fer est utilisé comme indicateur chronostratigraphique, nous n'avons littéralement aucune connaissance concernant les modèles liés à sa production durant l'Age de Fer et nous ignorons si des changements dans la technologie employée et dans le contexte socioculturel de la production du fer ont eu lieu. Le développement historique de l'exploitation du fer n'a jamais été étudié d'un point de vue à la fois archéologique et métallurgique. Par exemple, nous ne savons pas si des fours semblables ont été utilisés de manière continue au cours des deux derniers millénaires. Des fouilles réalisées au nord du Zimbabwe sur deux sites différents, l'un de tradition Gokomere-Ziwa (800-1200 cal AD) et l'autre de tradition Zimbabwe (1500-1700 cal AD), ont montré des différences au niveau des débris pyro-métallurgiques du fer, suggérant, provisoirement, des pratiques d'exploitation du métal indépendantes. En comparant les vestiges archéologiques et métallurgiques de ces deux sites, cet article représente un premier pas vers la description des modèles de production autochtone du fer dans une région du Zimbabwe.
\end{abstract}

Keywords: Gokomere-Ziwa, Zimbabwe tradition, iron working remains, slag tapping, tuyeres, natural draft

$\begin{array}{ll}\text { Shadreck Chirikure } & \text { Thilo Rehren } \\ \text { Materials Laboratory } & \text { Institute of Archaeology } \\ \text { Department of Archaeology } & \text { University College London } \\ \text { University of Cape Town } & 31-34 \text { Gordon Square } \\ \text { Rondebosch } & \text { London WC1H 0PY } \\ 7701 \text { Cape Town } & \text { England } \\ \text { South Africa } & \text { E-mail: th.rehren@ucl.ac.uk } \\ \text { E-mail: schirikure@yahoo.co.uk } & \end{array}$




\section{Introduction}

A large number of archaeologists and other specialists, such as linguists and historians, working in southern Africa believe that iron working was introduced by indigenous smelters and smiths who are ancestors of the modern Bantu (HUFFMAN 1971; SOPER 1982; Phillipson 1985; Hall 1987; Mrtchell 2001; PwitI 2005). Indigenous iron production and use has a relatively long history in the sub-continent (MILLER 2001, 2002). Since its emergence in the early first millennium $\mathrm{AD}$, the craft prospered for close to two thousand years only declining in the early years of colonialism, in the late nineteenth and twentieth century. It is generally agreed that the adoption and use of iron had revolutionary consequences in prehistoric societies since it introduced a potential source of wealth, tools for agricultural production, as well as weapons for territorial expansion and consolidation (DE MARET 1985; HaAland \& ShinNie 1985; DE BarRos 1988, 2000; KIYAGA-MuLINDWA 1993).

Archaeologists have traditionally divided the last two thousand years of southern African prehistory into two distinct cultural periods conventionally known as the Early and Late Iron Ages. Due to an increase in the use of absolute methods of dating it is now widely accepted that the so called EIA cultures represented by ceramic traditions such as Gokomere-Ziwa did not end around AD 1000 as thought earlier, but instead coexisted and overlapped with the early LIA cultures such as Gumanye and Leopard's Kopje for close to two centuries (Huffman 1986, 1996; Mitchell 2001; PIKIRAYI 2001). The division between the earlier Gokomere-Ziwa cultures and those that emerged in the early second millennium such as Leopard's Kopje is based on observable changes in material culture and different levels of socio-political and economic organisation. Apparent differences in pottery types and decorations, increase in trade, and the rise of chiefdom and state systems have been cited as factors that distinguishes the two cultural periods (FAGAN 1965; PHILLIPSON 1977; Huffman 1978; Hall 1987; Pwitr 2005). While these changes were recorded in other aspects of culture and society in general, not much consideration has been given to iron production and its potential to change over the course of two thousand years. Undoubtedly, high temperature technologies such as iron production were important in the societies and cultures of prehistoric populations (MILLER et al. 2001; MILLER \& KILLICK 2004). In addition, the production and use of iron was a socially mediated experience that merged the technical parameters of smelting and smithing with the belief systems of extant populations (NDORO 1991; ChILDS 1991, 1994, 2000; BARNDON 1996; SCHMIDT 1997; HAALAND 2004). With its deep rooted links in society, one would expect the production of iron to change as broader society developed.

However, in conventional reconstructions of southern African archaeology, iron production has been viewed as impervious to change, and its contributions to cultural developments of the different societies that arose in the past have not been fully explored. SuMmERs (1969) argued that although iron was universally worked in prehistoric societies, the metal may not have been important in stimulating societal transformations. Despite this, we know that iron played an important role in every aspect of life in bygone societies through its use in making utilitarian and expressive objects (De Maret 1985; HaAland \& ShinNie 1985; Childs \& Killick 1993; Kiyaga-Mulindwa 1993; ChILdS \& DEWEY 1996). The discovery of iron production evidence at the Gokomere-Ziwa site of Swart Village (cal AD 800-1200) and Baranda (AD 1500-1700) offered an opportunity to analyse the remains from the production process with a view to document continuity and change in the technology and its socio-cultural context over time. These two sites (Fig. 1) are also important in that they represent societies that were at different levels of socio-political organisation. During the late first and early second millennium $\mathrm{AD}$, complex societal transformations took place that led to the emergence of complexity in northern Zimbabwe. Gokomere-Ziwa sites such as Kadzi in the mid-Zambezi valley, Matanda Farm in Chesa and Swart Village near Madziwa communal lands have been associated with the transition from egalitarian societies to hierarchical polities in northern Zimbabwe(GARLAKE 1969; PWITI 1991, 1996; PIKIRAYI 1993, 2001).

The site of Baranda, situated in Chesa communal lands in Mt Darwin, is located within the heartland of the historical Mutapa state ( $16^{\text {th }}$ to $19^{\text {th }}$ century), a successor to Great Zimbabwe (1200 - 1450). The Mutapa state occupied a large territory in most of northern Zimbabwe and adjacent areas of Mozambique. The rulers built several capitals of which Baranda is but one example. Archaeological work carried out in the last fifteen years has shown that, compared to stone walled sites such as Mutota's Zimbabwe on the escarpment and Zvongombe in Centenary, Baranda was a later capital of the Mutapa state with no dry stone wall enclosures (Pikirayi 1993, 2001; Sinclair et al. 1993; CHIRIKURE et al. 2001). 


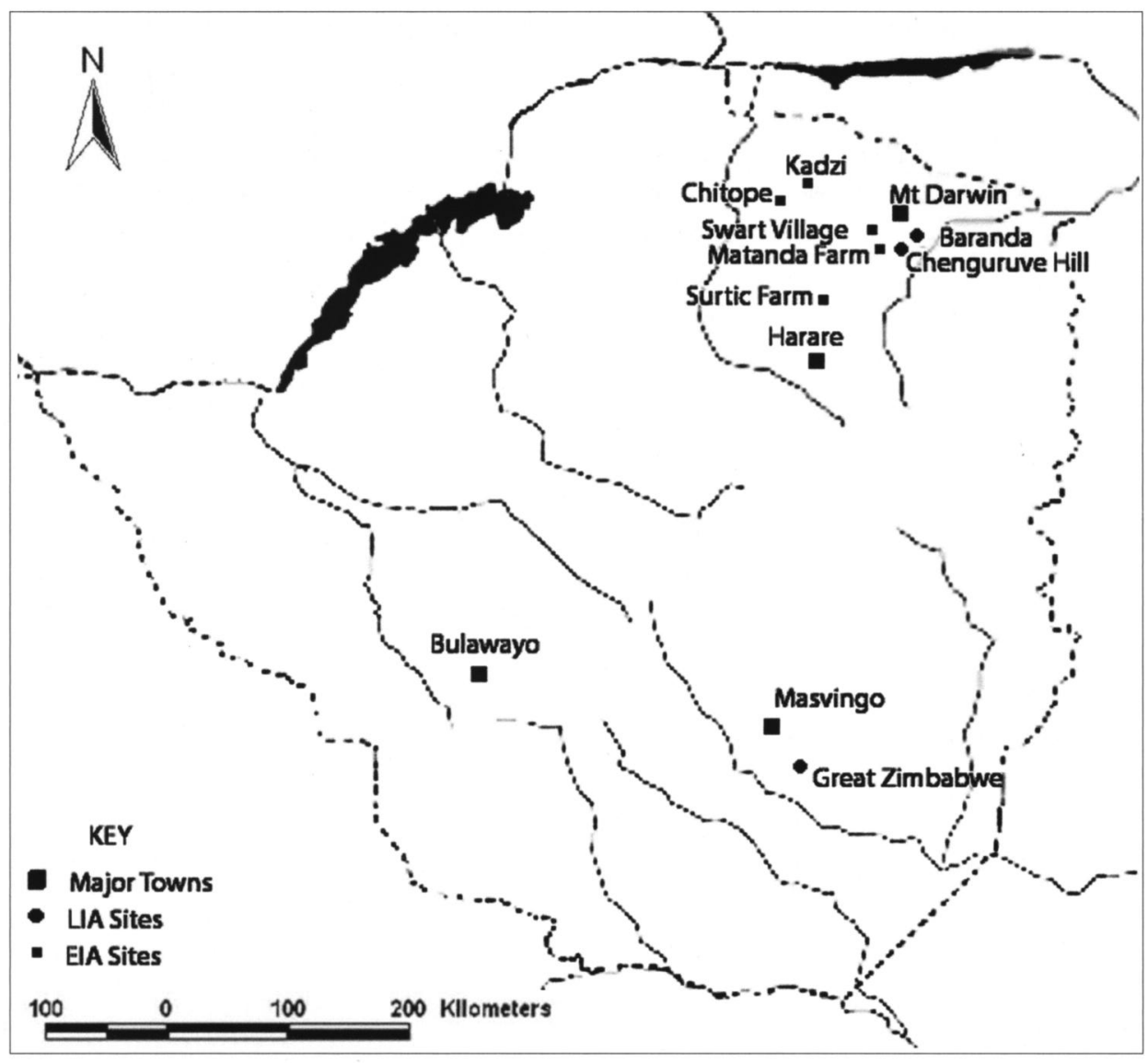

Fig. 1. Map of Zimbabwe showing the location of Swart Village and Baranda.

A comparison of material culture recovered from Zimbabwe tradition sites with that retrieved from the earlier Gokomere-Ziwa culture reveals marked and significant differences. For example, the large quantities of exotic goods such as glass beads, Chinese blue and white porcelain and glazed wares that were recovered in abundance at Baranda and Zvongombe have no match in the preceding period. In addition, there are also divergences in local artefacts such as domestic pottery with that from the earlier period being lavishly decorated with comb stamped designs and incisions which are rare in the rather plain and graphited pottery of the Zimbabwe period (HuffMan 1971; PwITI 1996; PIKIRAYI 2001). Because both Gokomere-Ziwa and Zimbabwe culture peoples were agriculturalists, iron was important in their subsistence and socio-cultural activities. Archaeological work conducted at Swart Village and Baranda has identified large quantities of iron working remains indicating that iron may have played an important role in the societies represented by the sites. Excavations were conducted at the two sites to retrieve contextualised data for studying iron production by the Gokomere-Ziwa and Zimbabwe tradition peoples. By making recourse to archaeological and archaeometallurgical evidence, this paper aims to study iron production in societies of the first and second millennium AD in northern Zimbabwe utilising Swart Village and Baranda as case studies.

\section{Background to the sites}

Dating to between cal AD 800 and 1200, the site of Swart Village is a huge and extensive Gokomere-Ziwa village settlement located on the western banks of the Mupfuri River in Mt Darwin, northern Zimbabwe. Extending from east to west, the site spreads over ten hectares. It was initially investigated by PIKIRAYI (1993) who noticed the broad similarities between pottery at the site with that from sites such as Kadzi and Chitope, tentatively dating them to the same period. From a typological viewpoint, the ceramics were indistinguishable from those of the other sites. Incisions, comb stamping, punctation, wavy lines and stab and drag formed the dominant decoration techniques at the sites (MARADZE 2001). These Gokomere-Ziwa ceramics are 
interspersed with architectural remains in the form of pole impressed earthen structure (dhaka) and remains of iron working. Interestingly, the iron production remains are scattered all over the site demonstrating that its production was widespread or that there was a large population with scattered foci of production. When compared with similar sites in the region, the ferro-metallurgical remains from Swart Village are more abundant as compared to Chitope (GARLAKe 1969), Kadzi (PwITI 1996), Matanda Farm (PIKIRAYI 2001), tentatively suggesting that the site may have been an important iron production centre in the past. In this regard, it was felt that an archaeological and archaeometallurgical study of iron production will give some insight into iron working in the societies of the late first to early second millennium $\mathrm{AD}$.

Located in Chesa communal lands, Baranda is a large site of the Zimbabwe tradition covering a two square kilometre area. Oral traditions argue that the decline of the state based at Great Zimbabwe in the south led to a trek northwards in search of new opportunities (ABRAHAM 1959; BeACH 1980; MudENGE 1988; PIKIRAYI 1993). These Zimbabwe tradition peoples then founded the Mutapa state and established the Zimbabwe tradition with its characteristic dry-stone walled buildings in northern Zimbabwe and adjacent lowlands. Successive Mutapa leaders were involved in trading relationships with the Portuguese from the $16^{\text {th }}$ century onwards and some Mutapas such as Mavura established alliances with the Portuguese to bolster their withering political fortunes (ABRAHAM 1959; ВЕACH 1980). Interaction with the Portuguese brought structural changes within the Zimbabwe culture. For example, whilst most of the earlier capitals such as Zvongombe, Nhunguza, Chisvingo and Mutota were typical dry-stone walled buildings, later capitals such as Baranda did not have the dry-stone walls (PIKIRAYI 1993). However, there is a great deal of similarity in the material culture found at Zvongombe, Mutota and other Zimbabwe tradition sites with that recovered from Baranda demonstrating that they all belong to one culture (PIKIRAYI 1993; CHIRIKURE et al. 2001). The material culture at the sites includes exotic products like Arabian wares, Chinese pottery and Indian blue and brown beads. The largest volume of exotic goods has been recovered from Baranda as compared to its sister sites demonstrating that it was an important political and economic centre (PIKIRAYI 1993; SINCLAIR et al. 1993). House floors, pole impressed earthen structure (dhaka), figurines and local pottery also form part of the inventory of artefacts and features recovered from the site. However, when juxtaposed with other sites of the Zimbabwe tradition in the north, Baranda stands out for possessing abundant evidence of iron working within settlements. The evidence includes remains of ore, slag, tuyeres and possible furnace fragments. PIKIRAYI's (1993) excavations demonstrated the contemporaneity between the iron working at the site and the occupation. The site thus offered an opportunity to explore in detail iron working at Zimbabwe type sites. Very few studies have been carried out so far on iron working at the Zimbabwe tradition sites to understand the nature of smelting and smithing.

It was largely believed that iron smelting during the Zimbabwe period was always practised outside residential areas because of the rituals associated with the process (BENT 1892; HUFFMAN 1986, 1993, 1996; HERBERT 1993). In contrast, smithing was less ritualised and was often practised inside settlements. Thus the evidence for iron working within the settlements was supposedly either associated with the less ritualised process of smithing or it was argued that iron smelting and the sites were not contemporary (VAN DER MERWE 1978), without even empirically determining the processes represented by the remains. This view was supported using late $19^{\text {th }}$ and early $20^{\text {th }}$ century ethnographies, in which iron was smelted outside settlement areas. Some researchers have therefore posited that the smithing inside and smelting outside dichotomy existed throughout the Iron Age (HufFMAN 1986, 1993). When taken together, the sites of Swart Village and Baranda were thus seen as crucial in understanding the role and development of iron working in the Iron Age at both inter-site and intra-site levels.

\section{Bloomery production of iron: A brief note}

As elsewhere, the production of iron in pre-colonial Zimbabwe was through the direct process whereby iron ore was reduced by carbon monoxide in charcoal fuelled furnaces of different designs to form a solid but spongy mass of metal called bloom, and liquid silicate waste, the slag (BACHMANN 1982; KILLICK 1991; MilleR \& KILLICK 2004). The bloom contained occluded slag and charcoal which were expelled during primary smithing to consolidate it into usable iron for fabrication into a variety of items. The direct method contrasts significantly with the blast furnace/indirect method exclusively used nowadays. In the indirect process, iron is produced as liquid cast iron which is subsequently decarburised to produce soft malleable 


\begin{tabular}{|ccccccc|}
\hline Context & $\begin{array}{c}\text { Presence of } \\
\text { concave casts }\end{array}$ & $\begin{array}{c}\text { Impressions of } \\
\text { thin sticks }\end{array}$ & $\begin{array}{c}\text { Charcoal } \\
\text { impressions }\end{array}$ & Magnetic & Non Magnetic & Corrosion \\
\hline Test Pit 1 & $15.7 \mathrm{~kg}$ & $6.9 \mathrm{~kg}$ & $5.2 \mathrm{~kg}$ & $5.8 \mathrm{~kg}$ & $24.2 \mathrm{~kg}$ & $2.2 \mathrm{~kg}$ \\
Test Pit 2 & $8.0 \mathrm{~kg}$ & $4.0 \mathrm{~kg}$ & $3.2 \mathrm{~kg}$ & $2.1 \mathrm{~kg}$ & $14.4 \mathrm{~kg}$ & $1.2 \mathrm{~kg}$ \\
Trench 1 & $5.5 \mathrm{~kg}$ & $2.0 \mathrm{~kg}$ & $3.0 \mathrm{~kg}$ & $1.9 \mathrm{~kg}$ & $11.3 \mathrm{~kg}$ & $2.7 \mathrm{~kg}$ \\
Trench 2 & $3.0 \mathrm{~kg}$ & $1.2 \mathrm{~kg}$ & $0.8 \mathrm{~kg}$ & $0.3 \mathrm{~kg}$ & $6.8 \mathrm{~kg}$ & $1.9 \mathrm{~kg}$ \\
Total wt & $32.2 \mathrm{~kg}$ & $14.1 \mathrm{~kg}$ & $12.2 \mathrm{~kg}$ & $10.1 \mathrm{~kg}$ & $56.7 \mathrm{~kg}$ & $8.0 \mathrm{~kg}$ \\
\hline
\end{tabular}

Tab. 1. Macroscopic characteristics of slag from Swart Village.

\begin{tabular}{|lcccccc|}
\hline Context & $\begin{array}{c}\text { Presence of } \\
\text { concave casts }\end{array}$ & $\begin{array}{c}\text { Impressions of } \\
\text { thin sticks }\end{array}$ & $\begin{array}{c}\text { Charcoal } \\
\text { Impressions }\end{array}$ & Magnetic & Non magnetic & Corrosion \\
\hline Trench 1 & - & - & $1.2 \mathrm{~kg}$ & $0.7 \mathrm{~kg}$ & $2.5 \mathrm{~kg}$ & $1.7 \mathrm{~kg}$ \\
Trench 2 & - & - & $0.2 \mathrm{~kg}$ & $0.1 \mathrm{~kg}$ & $0.4 \mathrm{~kg}$ & $0.1 \mathrm{~kg}$ \\
Trench 3 & - & - & $2.1 \mathrm{~kg}$ & $0.9 \mathrm{~kg}$ & $3.5 \mathrm{~kg}$ & $1.2 \mathrm{~kg}$ \\
Total & - & - & $3.5 \mathrm{~kg}$ & $1.7 \mathrm{~kg}$ & $6.4 \mathrm{~kg}$ & $3.0 \mathrm{~kg}$ \\
\hline
\end{tabular}

Tab. 2. Macroscopic characteristics of slag from Baranda.

or wrought iron. The ingredients for the bloomery production of iron are ore, air, charcoal, furnaces and blow pipes or tuyeres. Furnaces of different designs were operated with some being large shafts standing above the ground while others were shallow bowls in the ground. The air flow through the furnaces was generated through pumping the bellows or by natural draft using the chimney effect. Both natural draft and bellows driven furnaces have been documented in the Zimbabwean archaeological record (PRENDERGAST 1975, 1979). Natural draft furnaces are typically large, containing multiple tuyeres and had a provision for slag tapping. Bellows driven furnaces use a smaller number of tuyeres and are often smaller although they can be slag tapping just as their natural draft counterparts (KILliCK 1991; REHDER 2000). Prehistoric smelters exploited the advantages of each type of furnace though some authorities (REHDER 2000) have posited that natural draft furnaces were easier to operate and therefore may have been earlier. However, this is an over-simplified position since natural draft furnaces continued to be used in east Africa in the last hundred years together with bellows driven ones (SCHMIDT 1997). After smelting and smithing, the remains of iron production usually range from intact to collapsed furnaces, discarded slag, partially reduced ore and even lost blooms and finished products. As products of high temperature processes, these remains cohtain some partial histories of the processes which they have undergone. By analysing them in the laboratory it is possible to understand the technology of smelting and smithing practised at a given site. Thus by comparing iron production at archaeological sites dating to different periods, one can get an insight into the diachronic changes in iron working over time.

\section{Laboratory studies}

The excavated iron working remains were studied in the laboratory following standard metallographic procedures (ScotT 1991). Initially, the remains were studied macroscopically and observable features on the slag and tuyeres remains were recorded and compared by site. Tables 1 and 2 show the macroscopic features of slag and tuyeres from Swart Village and Baranda.

Figure 2 and Tables 1 and 2 highlight significant macroscopical differences on the iron extraction remains from the two sites. Whilst some of the slag from Swart Village has concave casts (Fig. 2d), none of the slags from Baranda demonstrate such features. Also, the metallurgical ceramics from the two sites differ significantly, which further suggests different metal working practices for the two sites. For instance, tuyeres from Swart Village are twice the diameter and thickness of those from Baranda (see Fig. 2). The significance of these differences will be discussed below. 

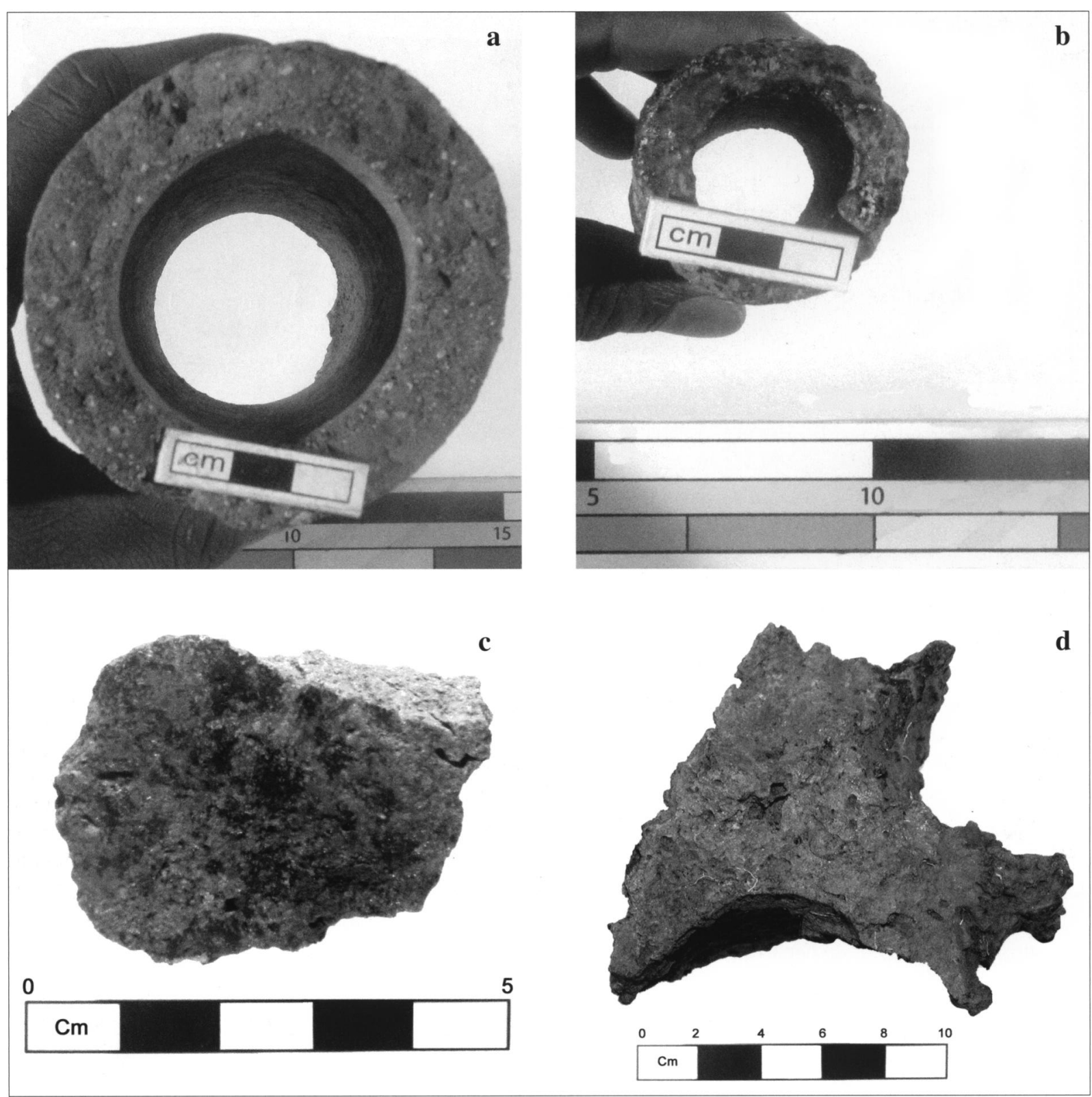

Fig. 2. Iron working remains from Swart Village and Baranda. a: tuyere fragment, Swart Village; b: tuyere fragment, Baranda; c: fragment of furnace wall, Baranda; d: slag with concave casts, Swart Village.

In order to understand the processes and individual episodes in the iron production cycle, the iron working remains from Swart Village and Baranda were classified into morphological groups on the basis of the stages which they represent in the production cycle. For iron smelting, these were remains of ore, furnace wall, broken tuyeres and slag (tap and furnace slag). The residues of smithing were hammerstones, anvils, smithing slag and crown material (see below for definitions). The reader is also referred to CHIRIKURE \& REHREN (2004) and MILLER \& KILLICK (2004) for detailed definitions of these material types. Any successful characteri- sation of iron working remains depends on a proper association between the morphologies, compositional data and mineralogical information (PLEINER 2000; MILLER \& KILLICK 2004). Great attention should be given to the archaeological context for such artefacts; in the case of Swart Village and Baranda, all the samples were retrieved from well documented contexts unequivocally linked with iron smelting and smithing.

Samples from each category of remains were selected and prepared as polished blocks for optical metallography, while bulk chemical analyses using 

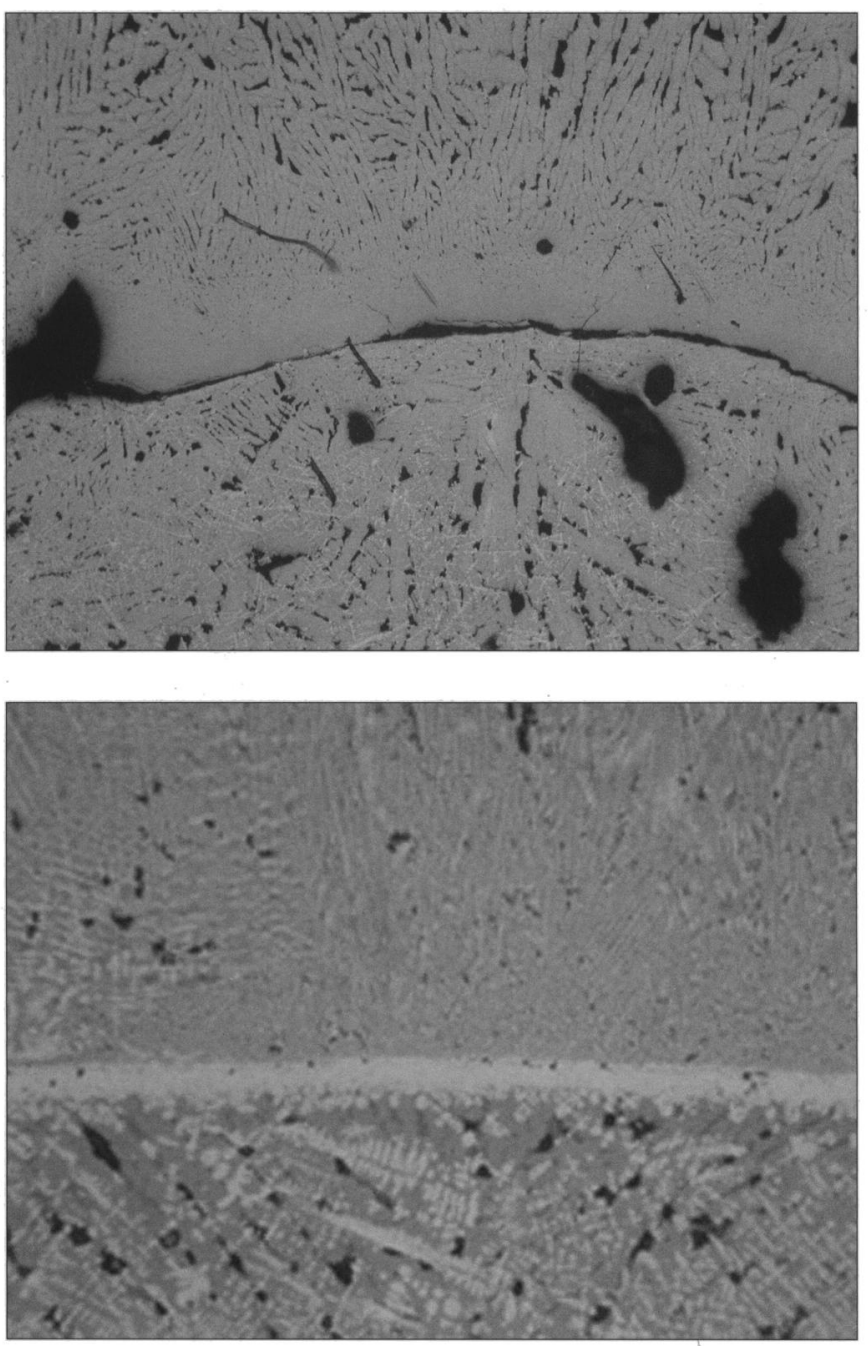

Fig. 3. Photomicrograph of flow slag from Swart Village and Baranda.

\begin{abstract}
a. Photomicrograph taken at $75 x$ magnification of a flow slag from Swart Village, showing the consecutive flow of fayalitic slag. The upper flow solidified in a glassy structure on contact with the lower flow and with a clear separation between them, indicating that the lower flow had fully cooled before the upper flow took place. This structure is typical of tapping and frequently found in the Swart Village material. (Sample SV7 Trench 1 Layer 3).
\end{abstract}

\begin{abstract}
b. Photomicrograph taken at $150 \mathrm{x}$ magnification of photomicrograph of flow slag from Baranda (sample BN10 Trench 3 Layer 1), showing a more welded contact between the two, including the formation of a magnetite skin (white) between them. While this texture is often found in tapping slags, it is rare in the Baranda material and may point to the accidental tapping of some slag during bloom removal.
\end{abstract}

energy dispersive XRF were done using pressed powder pellets and a calibration method developed specifically for iron rich materials (VELDHUIJZEN 2003); the results are detailed below. Full results of the XRF analyses are appended (see Appendix 1).

\section{Results for optical metallography}

\section{Tap/Flow Slag}

Slag with clear flow textures (see Fig. 3) is very diagnostic of smelting operations, and most often studied. It is formed from all the gangue components of the ore, i.e. those oxides which are not being reduced to metal, plus a considerable quantity of iron oxide chemically bonded to these other oxides and varying amounts of fuel ash and absorbed ceramic material from tuyeres and or the furnace wall. It carries structural information on some aspects of the process technology, visible on microscopic studies, as well as chemical information relating to the ore used and possible further components influencing the smelt, requiring quantitative analysis.

Slags at both sites had a similar mineralogical composition, being fayalitic $\left(\mathrm{Fe}_{2} \mathrm{SiO}_{4}\right)$ with wüstite $(\mathrm{FeO})$ in a glassy matrix. Approximately, the wüstite was between 50-60\% while fayalitic phases constituted most of the remaining 40-50\%. Noteworthy is the small amount of hercynitic spinels $\left(\mathrm{FeAl}_{2} \mathrm{O}_{4}\right)$ in the slag from Baranda, which has not been detected in similar materials from Swart Village. A sizeable number of samples from both sites had well developed magnetite skins on their flow surfaces that indicate different slag flows from the furnace, with the magnetite layers from Swart Village more clearly developed than those from Baranda. Furthermore, the fayalite in five out of fifteen samples from Swart Village had formed perpendicular to the cooling front or surface of the slag flow, a structure known as spinifex and indicative of rapid cooling, as typical in tap slags. By contrast, only one sample from Baranda 


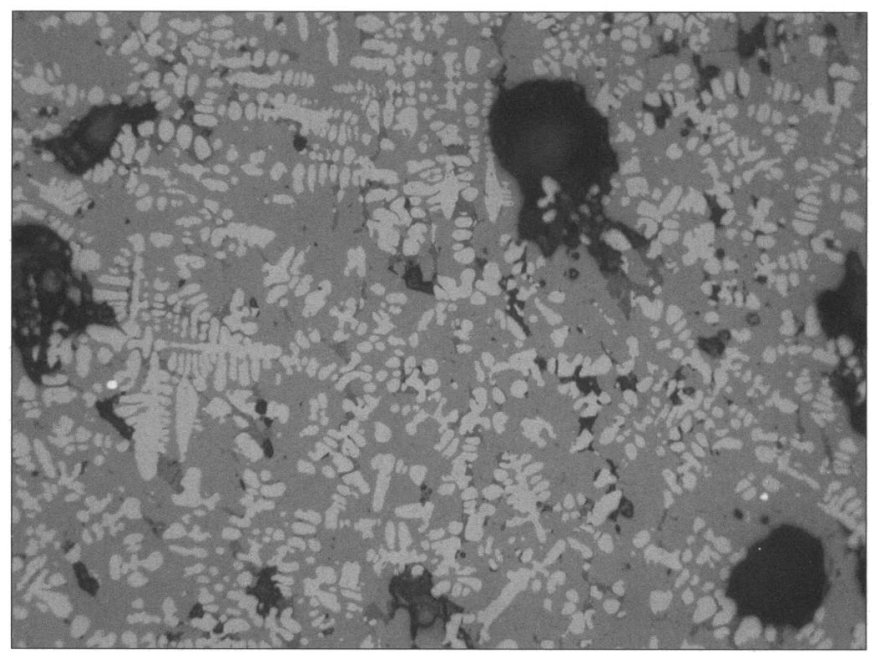

Fig. 4. Photomicrograph of furnace slag from Swart Village, 30x magnification. (Sample SV4 Trench 2 Layer 3). had developed such a structure. This demonstrates that most slags from the Gokomere-Ziwa site of Swart Village had reached a more fluid state and cooled more rapidly when compared to that from the Zimbabwe tradition site of Baranda. The absence of direct tapping evidence such as slag tapping holes or pits at the two sites means that slag tapping at the sites is only conjectural. We may assume, however, that tapping was a more regular part of the process at Swart Village, while at Baranda, it possibly occurred more accidentally when slag was flowing out of the furnace when removing the bloom through the rake hole.

Compositionally, the tap/flow slags from Swart Village and Baranda fall within the typical range of bloomery slags with between 50 and $60 \mathrm{wt} \% \mathrm{FeO}, 5-6$ $\mathrm{wt} \%$ alumina, and $15-20 \mathrm{wt} \%$ silica. There is a relatively high level of manganese in the slags, at around $11 \mathrm{wt} \%$ at Swart Village and 2 to $7 \mathrm{wt} \%$ at Baranda; due to similar chemical behaviour of manganese and iron oxides, the higher manganese oxide levels go together with lower iron oxide levels. The manganese oxide content in fayalite substitutes for iron during reduction. This explains why there is so much wüstite in these samples, while the bulk composition indicates relatively low iron oxide levels.

\section{Furnace slag}

Furnace slag (Fig. 4) is differentiated from tap/ flow slag by the lack of flow structures, and is supposed to have cooled within the furnace. Its morphology is characterised by irregular shapes, often containing charcoal impressions or adhering furnace wall material. Furnace slags can show flow structures, too, but without the magnetite skin typical of tap slag. Within the range of variation, this type of slag from the two sites was characterised by the dominance of wüstite $(60 \%)$, fayalite $(30 \%)$, a glassy matrix $(5 \%)$ and the porosity $(5 \%)$ constitute the rest though in some instances minute particles of metallic iron are visible. Both the fayalitic phases and the wüstite were in some cases dendritic while in others they were blocky demonstrating that some of the slag samples had cooled more quickly, as if removed during the opening of the furnace for the removal of the bloom, while others had cooled slowly, possibly within the furnace. The higher incidence of wüstite is significant and reflected in their higher total iron oxide level.

Compared to tap slags, the furnace slags possess a much higher $\mathrm{FeO}$ content (70-80 wt\%), and the ratios of the other oxides is slightly different. There is proportionally more silica than alumina, and the levels of lime, magnesia, potash and soda are lower, too. These differences are very clear for the Swart Village samples, but less pronounced for the Baranda slags, of which we have fewer samples and much more variable compositions within the morphological groups. These differences are consistent with the different morphologies; tap slag represents the most fluid part of the furnace charge dominated by a relatively high glass content and comprising proportionately more of fluxing alkali and earth alkali oxides. The furnace slag in contrast is more likely to contain the solid phases, primarily free iron oxide (wüstite) and the dominant silicate phase to crystallise, in this case fayalite. Neither of these two phases contain any of the alkali and earth alkali metal oxides, nor alumina; in the absence of significant amounts of hercynitic spinel alumina is mostly present in the glass phase, and therefore enriched in the tap 


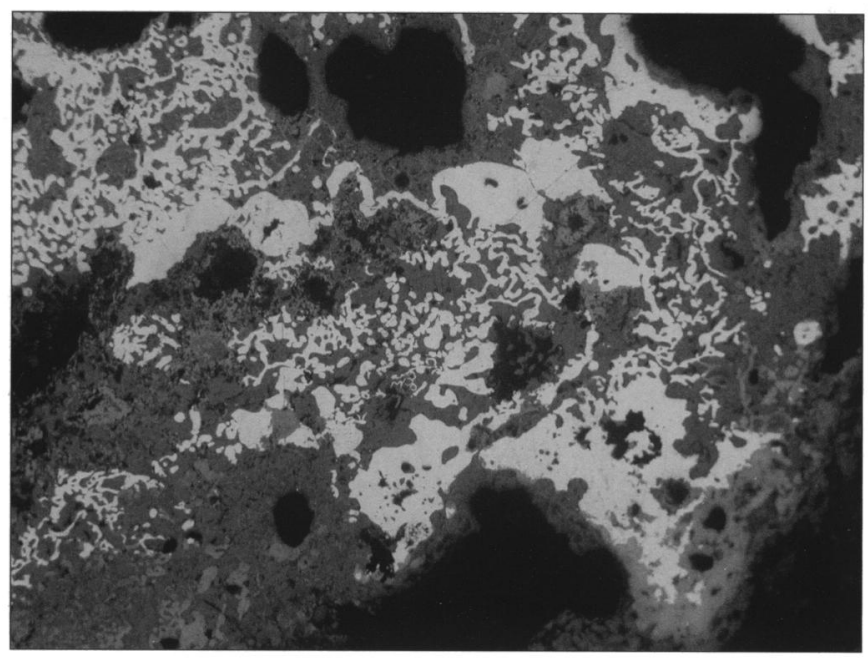

Fig. 5. Photomicrograph taken at $75 \mathrm{x}$ magnification of crown material from Baranda (Sample BN 12 Trench 1 Layer 3). The dominant phase here is metallic iron (bright), with some silicate phases and corrosion products (both dark grey) and a high degree of porosity (black). slag. The lower proportion of manganese, which does crystallise in fayalite, reflects the changing fayalite composition over the cooling cycle of the melt, with more iron-rich fayalite crystallising first, and therefore dominating in the furnace slag.

The rather sharp division between tap and furnace slags in their chemical composition for Swart Village underlines that the morphological distinction is based on real differences, while the much more blurry separation for the Baranda slags correlates with the much weaker indication for tapping, as mentioned above, and therefore reflecting more of a broad continuum of slag compositions as one would expect from a non-slag tapping furnace.

\section{Smithing slag and crown material}

We use the term "crown material" for fragments which have some aspects of the bloom but are still close to the furnace slag (Fig. 5); its content of metallic iron would have been removed by the smith prior to working the bloom. Some scholars on the bloomery process in Africa have discussed in detail the existence of partially reduced ore which in the chain of furnace reactions would not have reached the hottest zone such that the grains of metallic iron would not have coalesced into a bloom (KILLICK \& GoRdON 1988; Miller \& KILLICK 2004). Such materials possess a microstructure which is very similar to that of the material we call crown material. Based on the work carried out on slags from Nyanga, north-eastern Zimbabwe (CHIRIKURE \& REHREN 2004) and experimental work carried out by CREW (1991) in Wales, we prefer the term crown material rather than partially reduced ore. Most of the Nyanga crown material was rather blocky in size as distinct from partially reduced ores which in some cases were slagged and had fewer particles of metallic iron. In those samples, some iron oxide had visibly dissolved into the slag and has led us to believe that such material is distinct from crown material; however, the two are very similar products of a continuous process and may even form a continuum. In the Welsh experiment, the cleaning of the bloom resulted in the knocking off of lumps of crown material, which were clearly distinct and more consolidated than the partially reduced ore from the same smelt. Thus, crown material was initially physically attached to the bloom, and would have been removed by the smith prior to working the bloom. We therefore consider it part of the smithing slag assemblage, indicative of primary smithing of freshly smelted blooms, although it structurally is part of the smelting process. Smithing slag sensu strictu is formed during the smithing operation and comprise a mix of residual smelting slag, crown material, vitrified hearth material, fuel ash and partly oxidised bits of iron metal; it therefore is not only in its activity related origin but also in its structure and shape different from smelting slag. However, it must also be borne in mind that most of the remains from the bloomery process are part of a continuum, and it is often very difficult to isolate parts of the same process such as smelting slag, crown material, and smithing slag (MILLER \& KILLICK 2004).

The major phases visible in these materials are between 25 and $40 \%$ metallic iron, 20 to $40 \%$ each for wüstite and fayalite, and $10 \%$ porosity. With the microstructure being similar to the other types of slag, the only differentiating factor appears to be the relatively high level of metallic iron in these material types as 
compared to furnace slags for example. The fayalite was blocky indicating that the samples had cooled slowly and possibly inside the hearth or furnace. This material differs from real blooms in that the high level of wüstite and fayalite in them virtually make it impossible for the metallic iron to be consolidated into usable metal. Corrosion products are also visible on the edges of most of the samples indicating the oxidation of metallic iron after discard.

The smithing slags from the two sites are almost identical to the smelting slags in their mineralogy and chemical composition, with some slags showing features of the tap slag while others are closer to the furnace slags. This shows the difficulty of separating smelting from smithing slags (BACHMANN 1982; MILLER \& KILLICK 2004). Most of the material in the smithing slags would have originated from the smelting of the blooms and would therefore be very similar to the composition of the smelting slag. However, contextually, the slags defined here as part of the smithing process were associated with hammerstones and anvils. Morphologically, they were also distinct from the smelting slags.

Chemically, smithing slags and crown material are two distinct groups; the crown material is very rich in iron (expressed in the tables as iron oxide, but present in parts as metallic iron), reaching $85 \mathrm{wt} \% \mathrm{FeO}$. All other oxides are accordingly present at lower levels, with the same differential depletion observed earlier for the difference between tap and furnace slag. This underlines the fundamental relationship between all these slag types, with tap slag and the bloom forming the extreme ends of a stepped continuum. The Swart Village smithing slag, in contrast, follows a different pattern, with the high iron oxide level and low alkali and earth alkali metal oxide levels of the furnace slag, but the high alumina level of the tap slag and the lowest manganese oxide levels of the four slag types (tap, furnace, crown and smithing). As previously, no clear pattern emerges from the Baranda data; except for the highest iron oxide level in the crown material no differentiating features are apparent from the chemical composition of the various slag types.

\section{Undiagnostic slag}

A fifth slag group, not attributable to any of the former groups on macroscopic appearance, was labelled undiagnostic slag; for the Baranda material, it is indis- tinguishable from the tap and furnace slags, while for the Swart Village assemblage, two of the three samples stand out for their extremely low manganese oxide and rather high phosphorous oxide and lime content. Phosphorous and lime are typical fuel ash oxides, however, the high amount of $\mathrm{FeO}$ in these slags would rule them out as fuel ash slags as defined by Miller \& KILLICK (2004). These differences could suggest that this material belongs to a separate suite of slags, unrelated to the material studied so far; however, more research would be necessary to test this hypothesis.

\section{Ore}

A few samples were selected at both sites thought to represent the ore used; if they can be shown to be the source of the slag, they can inform subsequent discussions about efficiency and possible ceramic contributions to the smelt. Iron hydroxide minerals form about $80 \%$ of the samples from both sites, the rest being quartz particles and porosity. The possible ores from Swart Village had in contrast a very low iron oxide level of between 30 and $40 \%$. The microstructure of the Baranda ore is akin to that of roasted ore as there are some quantities of magnetite intermixed with lamelle of haematite. In addition to almost $80 \mathrm{wt} \%$ iron oxide, the ore contains just under $10 \mathrm{wt} \%$ manganese oxide as the main further component. Silica (4 to $6 \mathrm{wt} \%$ ) and alumina (1.5 to $3 \mathrm{wt} \%$ ) are the main gangue components, lime is below $1 \mathrm{wt} \%$. Clearly, this was a good ore which could be economically reduced to produce metallic iron.

\section{Technical ceramics}

The clays used to make metallurgical ceramics at the two sites were evaluated to determine if there was a conscious selection of clays for iron production. The tuyeres from Swart Village were tempered with crushed quartz-rich material, while the furnace walls were dominated by natural mineral inclusions in the ordinary clay matrix. On the other hand, the tuyeres and furnace walls from Baranda had an almost identical microstructure with about $25 \%$ quartz inclusions in natural clay. The quartz grains are not particularly angular which suggest that they were in the original clay rather than being deliberately added as crushed rock. Some of the samples were eroded with slag and had clear evidence of vitrification and wüstite was visible on the slagged parts. 
The separation based on mineral temper contents in the technical ceramics from Swart Village is not reflected in their chemical composition. Neglecting the first of the three tuyere analyses, which is contaminated by a significant slag component as evidenced by the very high iron oxide and lime level, there is hardly any difference in the composition of tuyeres and furnace wall samples. The only noticeable difference is in the soda and magnesia levels, which are lower in the tuyeres.

For Baranda material, however, there appears a significant difference in the phosphorous oxide and alumina contents, which are much higher in the tuyeres, and a matching lower silica content. This may indicate conscious selection of more refractory clays for the tuyeres, and is further reflected in the much thinner walls of the Baranda tuyeres compared to the Swart Village tuyeres (see above). It is tempting to speculate that the reduced wall thickness of the Baranda tuyeres and the higher quality of their clay is a response to a more limited availability of this clay, and a selection of it for the most demanding parts of the furnace design, a practice that has been noted by CHILDS (1989) in some parts of Tanzania. When comparing all ceramic samples across both sites, the Baranda furnace wall material does stand out as particularly low in alumina and high in alkali, earth alkali metal and iron oxides, all of which indicate low refractory qualities.

The high alumina, potash and phosphorous and mostly low iron oxide content of the Baranda tuyeres could point to a granitic origin; more fieldwork would be necessary to narrow down the potential source of this clay and to discuss the degree of extra effort required for its procurement compared to the local, less refractory, clay.

The iron working remains from the two sites were plotted on ternary diagrams (Figs. 6 and 7) to estimate the melting temperatures. These ternary diagrams are limited in that they present an ideal situation based on pure three-component systems and thus only approximate reality. However, combining manganese oxide with iron oxide and using the $\mathrm{FeO}-\mathrm{Al}_{2} \mathrm{O}_{3}-\mathrm{SiO}_{2}$ diagram accounts for well over $90 \mathrm{wt} \%$ of the constituent components, and makes the temperature estimates relatively reliable. As in most cases, the data plots neatly in the eutectic trough between wüstite, fayalite, and hercynite, with the crown and furnace slag samples falling towards the wüstite -rich corner. Only a few samples from each sites, and these only just plot outside this field, towards the cordierite composition. This is in close agreement with the observed dominance of wüstite in almost all samples and indicates a rather limited contribution of the ceramic material to the slagforming process in the smelt (VELDHUIJZEN \& REHREN 2005).

The slags have theoretical melting temperatures between 1150 and $1200^{\circ}$ Celsius, typical for bloomery slags. Smithing slags and crown material from the two stand out from the smelting slags by their high iron oxide content, approaching the ore composition. However, smelting and smithing slags grade into each other, and in both cases are the furnace and tap slags much richer in silica relative to alumina than can be explained by the ore composition alone. The tap slags in particular fall onto a line extending from the ore to the ceramic composition, going directly through the low melting eutectic trough and indicating that either the ore samples are not representative of the smelted ore, or that some technical ceramic, i.e. furnace wall and protruding tuyeres, richer in silica than the ore did contribute to the slag formation process.

\section{Discussion}

Drawing the macroscopic, microscopic and chemical analyses together, an attempt at reconstructing the phases in the iron production cycle can be made. So far the interpretation of these analyses has identified four types or classes of ferro-metallurgical remains: the ore, smelting (furnace and tap/flow) slag, smithing slag/ crown material, and technical/refractory ceramics. The occurrence of all four classes of finds together in the same archaeological contexts indicates that smelting and smithing may have been practised within close proximity. The ore at Swart Village is characterised by a high manganese and low lime content, mirrored in the smelting slag. In contrast, there is a low amount of silica relative to alumina (with a ratio of about $2: 1$ to $3: 1$ ) in the ore, while the slag have a ratio closer to $4: 1$, indicating a certain contribution of silica from the furnace wall or tuyeres. The differences between the morphological classes of slag are reflected in a slight but systematic variation in composition, consistent with the different fluidity of the various slag types. This separation is more clearly developed for the Swart Village assemblage than for the Baranda material, where the morphological features indicate a different furnace design, resulting in less differentiation between slag types. The two ore samples from Baranda are very 


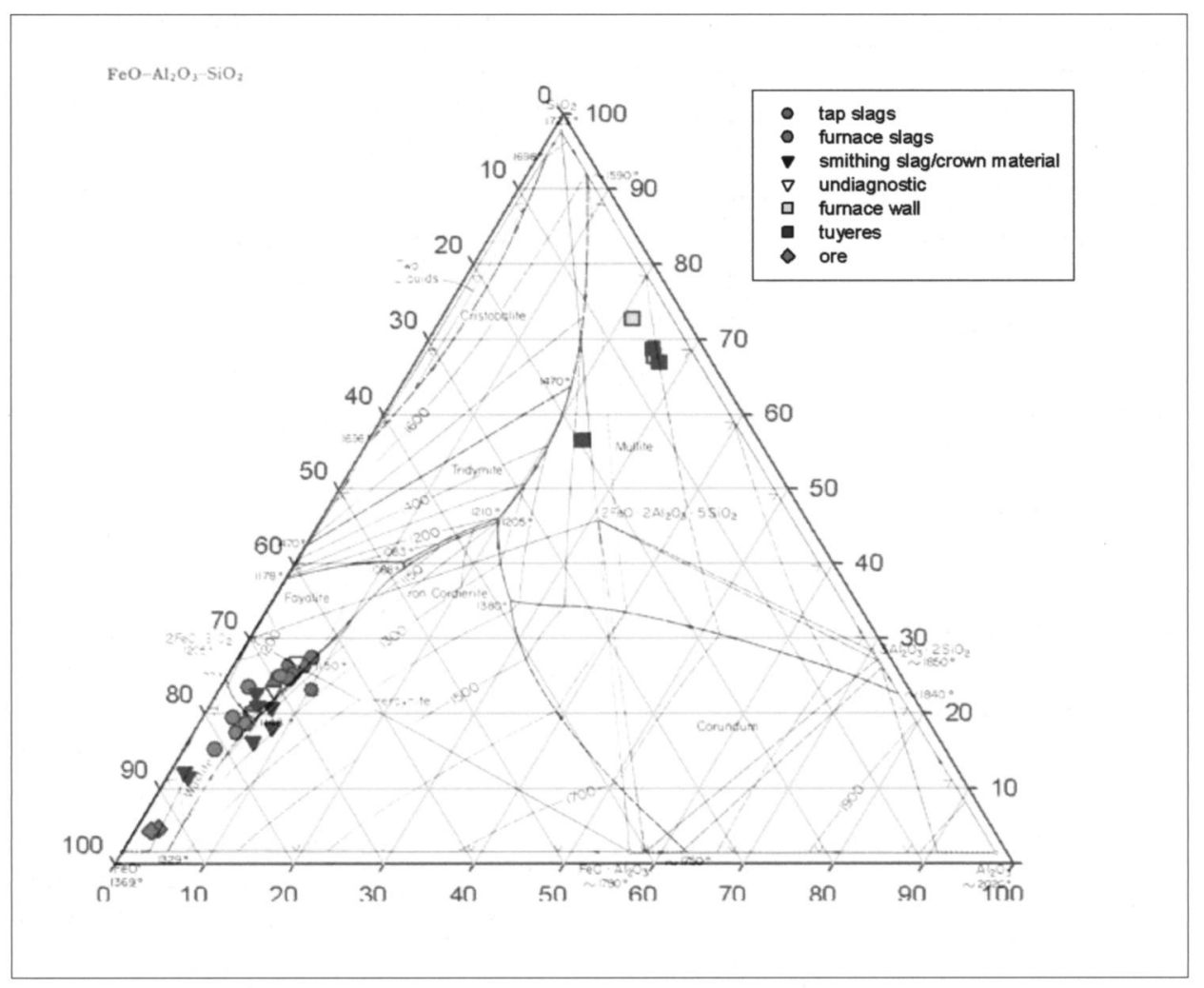

Fig. 6. Ternary diagram presentation of iron working remains from Swart Village.

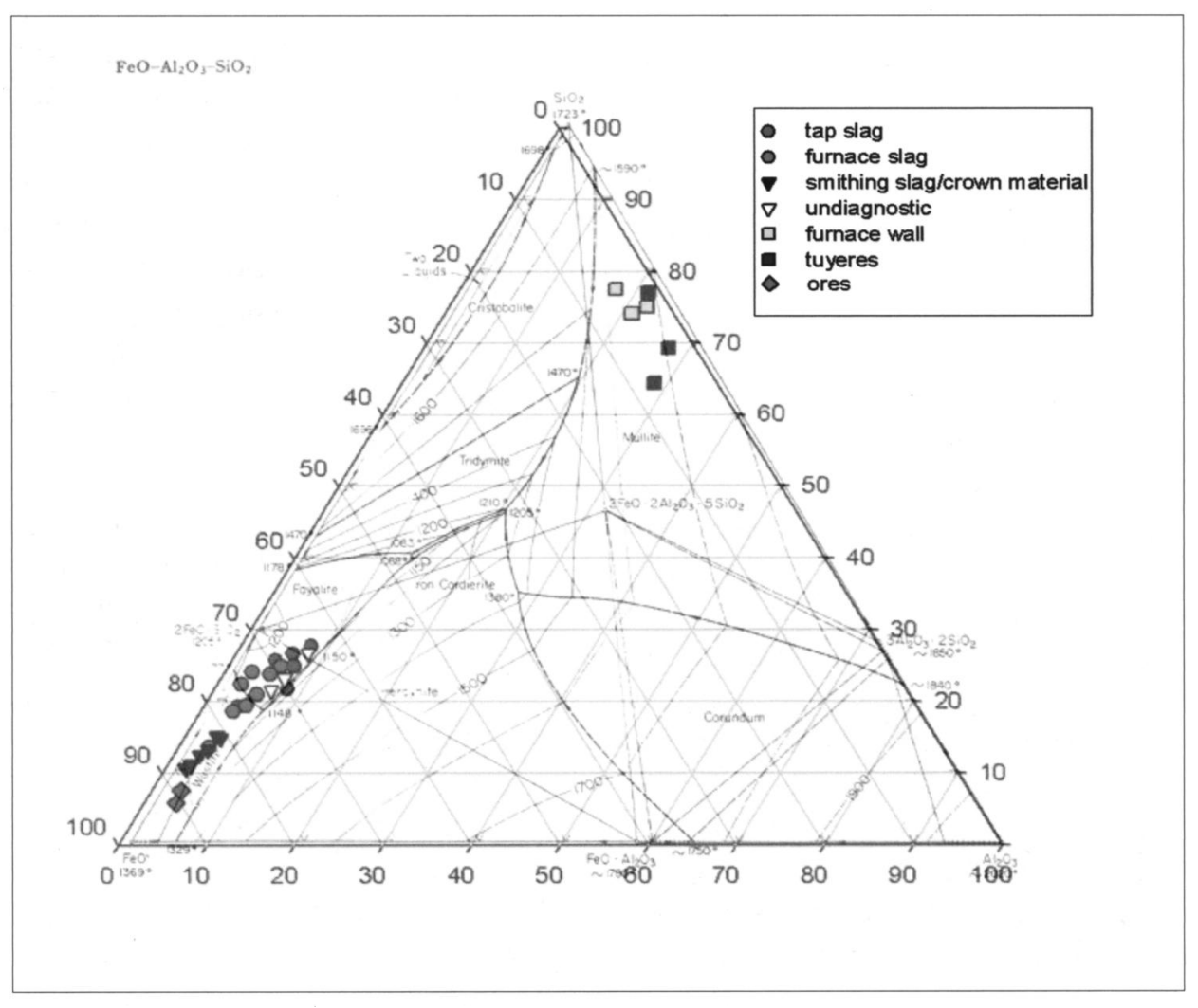

Fig. 7. Ternary diagram presentation of iron working remains from Baranda. 
similar in composition to the ores from Swart Village, with a similar high manganese content, low lime and low silica to alumina ratio; however, the slags from Baranda are on average not as rich in manganese oxide than those from Swart Village, and have lower lime and magnesia levels as well. The reasons for these differences are not clear at present, the lower manganese content could be due to the use or addition of a different ore, not covered by the few samples available, while the earth alkali metal oxides may reflect a different fuel to ore ratio, with relatively more fuel being used in the Swart Village furnaces.

\section{Iron smelting in the Early and Late Iron Age}

Iron working at Swart Village and Baranda thrived on exploiting iron rich ores that were self-fluxing, allowing for a limited contribution from the furnace wall and fuel ash. The ores may have been taken from different sources albeit with a related geological make-up as shown by the similarity between the slag chemistry and mineralogy of ores from the two sites. In particular, this interpretation is supported by the similar levels of manganese in the slags from both sites. In iron smelting, manganese rich ores had an advantage in slag metal separation in that the element assumed the role of iron oxide in the slag thus enhancing the yield of iron. In addition to the possible variation in fuel to ore ratio, indicated by the lime and potash levels, there are differences in slag morphology: the concave casts/stick impressions possibly suggest different methods of slag removal at the sites.

\section{Efficiency of the process}

Efficiency is a multi-layered parameter in most processes. Main factors relevant in this context are the efficiency in iron removal from the ore, efficiency in labour use, fuel consumption, and time efficiency. Their relative importance will differ from site to site, according to their socio-economic contexts. In this study, we have direct data only for the efficiency of iron removal from the ore, as expressed by the residual content of iron oxide in the slag, giving some insight into the skill of the operators of the furnaces (MORTON \& WINGROVE $1969,1972)$. There is little difference in the residual amount of iron oxide in the slags from Baranda as compared to those from Swart Village, indicating that the Late Iron Age iron production was not more efficient than its predecessor as pointed out by MILLER \&
KILLICK (2004). Assuming similar ore qualities, there seems to be no major development in the iron metal yield per quantity of ore from the terminal EIA to the early LIA; however to judge the efficiency of the process, the other parameters have to be considered in addition to the metal yield, particularly the economies of time, fuel and labour, which are not immediately visible from the chemical analysis of slag.

\section{Furnace types}

Macroscopic observations reveal important differences in the furnaces employed at Swart Village and Baranda as inferred from tuyere sizes and slag morphology. Though no standing furnace structures were recovered, the sizes of tuyeres from Swart Village indicate that from a functional/thermodynamics perspective, furnaces employed at the site were very large, an observation supported by the existence of large blocks of slag. PRENDERGAST (1983: 32) excavated iron furnaces dating to the EIA in northern Zimbabwe and concluded that they were probably driven by natural draught. Apart from being internally oxidised, the tuyeres from the Surtic Farm furnaces had average internal diameters of around $40 \mathrm{~mm}$ and external ones of closer to $62 \mathrm{~mm}$. In addition, most of the slag had flow structures reminiscent of tapped slag. In a ground breaking paper on natural draft furnaces, KILLICK (1991: 63) has posited that most of the natural draft furnaces used in southern Africa were slag tapping. These characteristics of natural draft furnaces are strongly represented by the material from Swart Village. As such we may assume that the flow slag from the site, the internally oxidised tuyeres, and the large internal diameter of the tuyeres indicate that the furnaces were natural draft operated. In contrast, furnaces from Baranda were comparatively smaller and possibly bellows driven; their tuyere diameters are only 20 to $30 \mathrm{~mm}$, much more in line with typical forced draught furnaces (KILLICK 2004). The furnace from PikiRaYI's (1993) excavations at Baranda was very small and similar to short shaft furnaces employed at Chenguruve Hill, a site that post dates Baranda by a century or two. From a metallurgical point of view, short bellows driven furnaces are generally considered more efficient in the amount of time required to reduce iron. KILLICK's (2004) studies in Malawi have shown that induced draught furnaces took about four or five days to produce iron while it took between four and five hours in a bellow driven furnace. If indeed the furnaces at Swart Village were natural draught and the Baranda furnaces forced draught, 
then the change from induced draught furnaces to bellows driven furnaces in the Iron Age of northern Zimbabwe may have resulted in more time efficiency in iron production. A further potentially important consideration is the different fuel efficiency of the two operations, with the later furnaces using less fuel; however, at present not enough studies of fuel to ore ratios are available to reliably explore this hypothesis. Gains in labour from reduced demand for charcoal for fuel consumption would at least have been partly offset by the requirement for additional labour to operate the bellows during the smelt. In addition, aspects of wood availability and competing demands for fuel for different needs further complicate this discussion.

There is an interesting difference with respect to utilisation of clay resources in building iron working installations at the two sites. At Swart Village, the iron workers seem to have added finely crushed quartz grains as tempering material in tuyeres, which is quite distinct from the generally coarse inclusions in the furnace wall; the clay base though seems to be the same for both types of technical ceramic. In Baranda, in stark contrast, the tuyeres are made from a very different clay than the furnaces; the latter were of a not particularly refractory nature, while the tuyeres were manufactured from a high-alumina clay, probably necessary to enable the production of thin walled and heat resistant tuyeres. If the assumption is right that the earlier furnaces were natural draught and relatively big, probably with many tuyeres, and the later furnaces small with just a few tuyeres, then there would be considerable pressure on the performance characteristics of the later tuyeres; failure of one out of just one or two tuyeres would have had a more severe effect on the smelt than in the typical multi-tuyere natural draught furnaces. The higher levels of iron oxide in the tuyeres from Swart Village meant that they were not particularly refractory and would slowly corrode to help in the slag formation process.

\section{Refining the bloom and forging tools}

The characteristics of the possible smithing slag and crown material appears to be similar for the two sites. Despite this, it must be mentioned that it is difficult to define smithing slags on the basis of mineralogy and chemistry alone (MORTON \& WINGROVE 1969; BaChMan 1982; Miller et al. 1995; Miller \& Killick 2004). Irrespective of this, the crown material/smithing slag has been positively identified within a reasonable degree of reliability despite the failure to recover smithing hearths or smithing hearth bottoms. The smithing slag was not only heterogeneous but it had angular impressions of charcoal, characteristics of smithing slag at some southern African sites (GREENFIELD \& MILLER 2004). The recovery of a diorite hammer stone at Swart Village further indicates that smithing was likely practised in the same contexts as smelting. It would have been interesting to analyse metal products from the two sites with a view to compare the quality of the iron produced. However, not any single finished iron product was recovered from the excavations and it is hoped that future work at the site may find the iron objects and thus contribute towards a fuller understanding of iron working in Iron Age northern Zimbabwe.

\section{Conclusion}

Archaeological and archaeometallurgical evidence has revealed important similarities and differences in iron production at Swart Village and Baranda in northern Zimbabwe. As in other categories of material culture at the sites, there were some changes and matching continuities in the working of iron. This is for instance shown by the large size of tuyeres that were used at Swart Village as compared to the small ones from Baranda. The existence of tapped slag in high frequency and the internally oxidised tuyeres further suggest the operation of natural draft furnaces and or tapping furnaces which contrast with the non-slag tapping and possibly bellows driven furnaces used by smelters at Baranda. This seems to support the remark made by PRENDERGast (1983) that different types of furnaces may have been used in northern Zimbabwe over the course of the Iron Age. However, chemically there seem to be no major differences in iron extraction in the cultural periods represented by the two sites. The residual amount of iron oxide and the overall chemistry of the slags are almost identical, indicating the use of a related ore and similar efficiency of the process. This is also corroborated by the matching similarities in the mineralogy of the iron working remains. There appear, however, to be differences with respect to clay utilisation at the sites. At Swart Village the smelters seem to have used the same clay but with different temper for furnace construction and tuyeres. In contrast, at Baranda no temper seems to have been added but the smelters selected different clays, sufficiently refractory to make very thin tuyeres which endured until the end of the smelting operation, but less refrac- 
tory clay for the furnace itself. Also, most of the evidence from Baranda is indicative of iron smelting and points to smelting in domestic areas, hitherto associated with smithing only. This suggests the existence of variation in the socio-spatial organisation of iron working in the time and space continuum. These similarities and differences thus underline the need to reconstruct local histories of iron production in northern Zimbabwe and beyond.

\section{Acknowledgements}

This paper is a modified version of a presentation made at the Society for Africanist Archaeologists Conference held in Bergen, June 2004. Without the funding and logistical support from the Institute of Archaeology, UCL, Archaeology Unit of the University of Zimbabwe and the Wenner-Gren Foundation, this research would not have been possible. Professors Gilbert Pwiti and Innocent Pikirayi accompanied Shadreck to the field during reconnaissance work and their ideas are deeply appreciated. We are very grateful to David Killick and the anonymous referee who gave us invaluable comments that greatly improved this paper. The metallurgical analyses were carried out at the Wolfson Archaeological Science Laboratories, Institute of Archaeology, UCL.

\section{References}

Abraham, D.P. 1959. The Monomotapa Dynasty. NADA 36, 59-84.

Bachmann, H.-G. 1982. The Identification of Slags from Archaeological Sites. Institute of Archaeology Occasional Paper No. 6. London.

Barndon, R. 1996. Mental and material aspects of iron working: A cultural comparative perspective. In: Pwiti, G. \& Soper, R. (eds.), Aspects of African Archaeology. Papers from the $10^{\text {hh }}$ Pan African Congress for Prehistory and related studies. University of Zimbabwe Publications, Harare, pp. 761-771.

Beach, D.N. 1980. The Shona and Zimbabwe, 900-1850: An Outline of Shona History. Mambo Press, Gweru.

Bent, T. 1892. The Ruined Cities of Mashonaland. Macmillan, London.

Childs, S.T. 1991. Style, technology, and iron furnaces in Bantu speaking Atrica. Journal of Anthropological Archaeology 10, 332-359.

Childs, S.T. 1989. Clays to artefacts. Resource selection in African Early Iron Age iron-making technologies. In: Bronitsky, G. (ed.), Pottery Technology: Ideas and Approaches. Westview Press, Boulder, pp. 139-164.
Childs, S.T. 1994. Society, culture and technology in Africa: An introduction. In: Childs S.T. (ed.), Society, Culture and Technology in Africa. MASCA Research Papers in Science and Archaeology. Supplement to Volume 11, 6-12.

Childs, S.T. 2000. Traditional iron working: A narrated ethnoarchaeological example. In: Bisson, M., Childs, S.T., de Barros, P. \& Holl, A.F.C. (eds.), Ancient African Metallurgy: The Socio-Cultural Context. Altamira Press, Walnut Creek, pp. 199-255.

Childs, S.T. \& Killick, D. 1993. Indigenous African metallurgy: Nature and culture. Annual Review of Anthropology 22, 317-337.

Childs, S.T. \& Dewey, W. 1996. Forging symbolic meaning in Zaire and Zimbabwe. In: Schmidt, P. (ed.), The Culture and Technology of African Iron Production. University Press of Florida, Gainesville, pp. 145-171.

Chirikure, S. \& Rehren, Th. 2004. Ores, slags and furnaces: Aspects of iron working in the Nyanga complex. African Archaeological Review 21, 135-152.

Chirikure, S., Pikirayi, I. \& Pwiti, G. 2001. A comparative study of Khami pottery Zimbabwe. In: Chami, F. \& Pwiti, G. (eds.), Southern Africa and the Swahili World. Dar es Salam University Press, Dar es Salam, pp. 106-131.

Crew, P. 1991. The iron and copper slags at Baratti, Populonia, Italy. Historical Metallurgy 25 (2), 109-115.

De Barros, P. 1988. Societal repercussions of the rise of traditional iron production: A West Atrican example. African Archaeological Review 6, 91-114.

De Barros, P. 2000. Iron metallurgy: Sociocultural context. In Bisson, M., Childs, T., de Barros, P. \& Holl, A.F.C. (eds.). Ancient African Metallurgy: The Socio-Cultural Context. Altamira Press, Walnut Creek, pp.147-198.

De Maret, P. 1985. The smith's myth and the origins of leadership in central Africa. In: Haaland, R. \& Shinnie, P. (eds.), African Iron Working: Ancient and Traditional. Norwegian University Press, Oslo, pp. 73-87.

Fagan, B. 1965. Southern Africa in the Iron Age. Thames and Hudson, London.

Garlake, P. 1969. Chitope: An Early Iron Age village in northern Mashonaland. Arnoldia 4, 1-14.

Greenfield, H. \& Miller, D. 2004. Spatial patterning of Early Iron Age metal production at Ndondondwane, South Africa: The question of cultural continuity between the Early and Late Iron Ages. Journal of Archaeological Science 31 (11), 1511-1532.

Haaland, R. \& Shinnie, P. (eds.) 1985. African Iron Working. Ancient and Traditional. Norwegian University Press, Oslo.

Haaland, R. 2004. Iron smelting - a vanishing tradition: Ethnographic study of this craft in south western Ethiopia. Journal of African Archaeology 2 (1), 65-81.

Hall, M. 1987. The Changing Past: Farmers, Kings, and Traders in Southern Africa 200-1860. David Philip, Cape Town. 
Herbert, E. 1993. Iron, Gender and Power: Rituals of Transformations in African Iron Working. Indiana University Press, Bloomington.

Huffman, T.N. 1971. A Guide to the Iron Age of Northern Mashonaland. Occasional Papers of the National Museums of Rhodesia 4, 20-44.

Huffman, T.N. 1978. The origins of the Leopard's Kopje Tradition: An $11^{\text {th }}$ century Difaquane. Arnoldia 7, 1-12.

Huffman, T.N. 1986. Iron Age settlement patterns and the organisation of class distinction in southern Atrica. World Archaeology 5, 291-338.

Huffman, T.N. 1993. Broederstroom and the Central Cattle Pattern. South African Journal of Science 89, 220-226.

Huffman, T.N. 1996. Snakes and Crocodiles: Symbolism and

Power at Great Zimbabwe. Witwatersrand University Press, Johannesburg.

Killick, D. 1991. A little known extractive process: Iron smelting in natural draft furnaces. JOM (Journal of the Minerals, Metals, and Materials Society) 43 (4), 62-64.

Killick, D. 2004. The most versatile technology? The bloomery iron smelting in Africa. Paper Presented at the Data and Material Science Group Seminar. Institute of Archaeology, UCL.

Killick, D. \& Gordon, R. 1988. The mechanism of the bloomery process. In: Farquhar, R.M., Hancock, R.G. \& Pavlish, L. (eds.), Proceedings of the $26^{\text {th }}$ International Symposium on Archaeometry (Toronto), pp. 120-123.

Kiyaga-Mulindwa, D. 1993. The Iron Age peoples of east-central Botswana. In: Shaw, T., Sinclair, P., Andah, B. \& Okpoko, A. (eds.), The archaeology of Africa: Food, Metals and Towns. Routledge, London, pp. 386-390.

Maradze, J. 2001. Early Farming Community Pottery from Swart Village and Matanda Farm, Northern Zimbabwe. Unpublished B. A. Honours Dissertation, University of Zimbabwe.

Miller, D. 2001. Indigenous iron production in southern AfricaArchaeological observations and interpretation. Mediterranean Archaeology 14, 229-234.

Miller, D. 2002. Smelter and smith: Iron Age metal fabrication technology in southern Africa. Journal of Archaeological Science 29, 1083-1131.

Miller, D. \& Killick, D. 2004. Slag identification at Southern African archaeological sites. Journal of African Archaeology 2(1), 23-49.

Miller, D. Boeyens, J. \& Kusel, M. 1995. Metallurgical analyses of slags, ores and metal artefacts from archaeological sites in the Northwest Province and Northern Transvaal. South African Archaeological Bulletin 50, 39-45.

Miller, D., Killick, D. \& van der Merwe, N. 2001. Metalworking in the Northern Lowveld, South Africa, AD 1000-1890. Journal of Field Archaeology 28, 401-417.

Mitchell, P. 2001. Southern African Archaeology. Cambridge University Press, Cambridge.
Morton, G. \& Wingrove, J. 1969. Constitution of bloomery slag: Part 1: Roman. Journal of the Iron and Steel Institute 207, 1556-1564.

Morton, G. \& Wingrove, J. 1972. Constitution of bloomery slag: Part 2: Medieval. Journal of the Iron and Steel Institute $210,478-488$.

Mudenge, S. 1988. A Political History of Munhumutapa. Zimbabwe Publishing House, Harare.

Ndoro, W. 1991. Why decorate her? Zimbabwea 1, 5-13.

Phillipson, D.W. 1977. The Later Prehistory of Eastern and Southern Africa. Heinemann, London.

Phillipson, D.W. 1985. African Archaeology. Cambridge University Press, Cambridge.

Pikirayi, I. 1993. The Archaeological Identity of the Mutapa State: Towards an Historical Archaeology of Northern Zimbabwe. Studies in African Archaeology 6. Societas Archaeologica Uppsaliensis, Uppsala.

Pikirayi, I. 2001. The Zimbabwe Culture: Origins and Decline of Southern Zambezian States. Altamira Press, New York.

Pleiner, R. 2000. Iron in Archaeology. The European Bloomery Smelters. Archeologicky ustav AV CR, Praha.

Prendergast, M.D. 1975. A new furnace type from Darwendale Dam Basin. Rhodesian Prehistory 7, 16-20.

Prendergast, M.D. 1979. Iron Age settlement and economy in part of the southern Zambezian Highveld. South African Archaeological Bulletin 34, 111-119.

Prendergast, M.D. 1983. Early Iron Age furnaces at Surtic Farm near Mazowe River, Zimbabwe. South African Archaeological Bulletin 38, 31-32.

Pwiti, G. 1991. Trade and economies in southern Africa: The archaeological evidence. Zambezia 18, 119-129.

Pwiti, G. 1996. Continuity and Change: An Archaeological Study of Farming Communities in Northern Zimbabwe, AD 500-1700. Societa Archaeologica Uppsaliensis, Uppsala.

Pwiti, G. 2005. Southern Africa and the East African coast. In Stahl, A. (ed.), African Archaeology: A Critical Introduc tion. Blackwell, London, pp. 378-392.

Rehder, J.E. 2000. The Mastery and Uses of Fire in Antiquity. McGill-Queen University Press, London.

Schmidt, P.R. 1997. Iron Technology in East Africa: Symbolism, Science and Archaeology. James Currey, Oxford.

Scott, D. 1991. Metallography and Microstructure of Ancient and Historic Metals. Paul Getty Trust, Marina del Rey (California).

Sinclair, P., Pikirayi, I., Pwiti, G. \& Soper, R. 1993. Urban trajectories on the Zimbabwean plateau. In: Shaw, T. Sinclair, P., Andah, B. \& Okpoko, A. (eds.), The Archaeology of Africa: Food, Metals and Towns. Routledge, London, pp. 365-388. 
Soper, R. 1982. Bantu expansion into eastern Africa: Archaeological evidence. In: Ehret, C. \& Posnansky, M. (eds.), The Archaeological and Linguistic Reconstruction of African History. University of California Press, Berkeley, pp. 223-238.

Summers, R. 1969. Ancient Mining in Rhodesia. National Museum of Rhodesia Memoir 3. Salisbury.

Van der Merwe, N.J. 1978. Field methodology and Iron Age metallurgy at Buhwa, Rhodesia. Occasional papers, National Museums and Monuments of Rhodesia Ser. A. 4, 101-105.
Veldhuijzen, H.A. 2003. Slag_fun, a new tool for Archaeometallurgy: Development of an analytical (P)EDXRF method for iron rich materials. PIA 14, 102-118.

Veldhuijzen, H.A. \& Rehren, Th. 2005. Iron smelting slag formation at Tell Hammer (az-Zarqa), Jordan. Proceedings of 34th International Symposium of Archaeometry Zaragoza (Spain) May 3-7, 2004.

\section{Appendix 1: XRF results for Swart Village and Baranda}

\begin{tabular}{|c|c|c|c|c|c|c|c|c|c|c|c|}
\hline Swart Village & $\mathrm{Na}_{2} \mathrm{O}$ & MgO & $\mathrm{Al}_{2} \mathrm{O}_{3}$ & $\mathrm{SiO}_{2}$ & $\mathbf{P}_{2} \mathbf{O}_{5}$ & $\mathbf{K}_{2} \mathbf{O}$ & $\mathrm{CaO}$ & $\mathrm{TiO}_{2}$ & MnO & $\mathrm{FeO}$ & Total \\
\hline \multicolumn{12}{|l|}{ Tap Slag } \\
\hline SVT2 L2 & 0.57 & 2.10 & 6.88 & 22.60 & 0.24 & 1.42 & 2.76 & 0.24 & 11.00 & 53.02 & 100.50 \\
\hline SVT1 L1 & 0.41 & 2.21 & 5.06 & 21.80 & 0.28 & 0.97 & 1.93 & 0.17 & 10.52 & 60.84 & 104.19 \\
\hline STV1 L3 & 0.42 & 2.14 & 6.72 & 22.50 & 0.24 & 1.38 & 2.65 & 0.24 & 8.45 & 56.13 & 102.60 \\
\hline SVT2 L3 & 0.49 & 2.13 & 9.07 & 20.20 & 0.24 & 1.38 & 2.66 & 0.24 & 9.56 & 58.02 & 106.43 \\
\hline SVT2 L1 & 0.60 & 1.13 & 6.05 & 25.78 & 0.43 & 1.49 & 2.21 & 0.29 & 11.45 & 65.71 & 115.14 \\
\hline SVT2 L2 & 0.58 & 2.13 & 6.98 & 23.87 & 0.21 & 1.42 & 2.79 & 0.24 & 11.89 & 63.45 & 113.56 \\
\hline SVT2 L3 & 0.50 & 2.15 & 6.75 & 23.16 & 0.23 & 1.40 & 2.68 & 0.23 & 11.52 & 64.23 & 112.85 \\
\hline SVT4 L1 & 0.51 & 2.16 & 5.54 & 21.93 & 0.22 & 1.56 & 2.23 & 0.25 & 11.63 & 65.10 & 111.13 \\
\hline \multicolumn{12}{|l|}{ Furnace Slag } \\
\hline SVT3 L2 & 0.52 & 0.88 & 3.32 & 14.30 & 0.41 & 0.47 & 0.47 & 0.06 & 4.00 & 76.23 & 100.66 \\
\hline SVT1L3 & 0.07 & 1.71 & 3.34 & 18.90 & 0.09 & 0.67 & 0.89 & 0.08 & 5.20 & 74.64 & 105.50 \\
\hline SVT2 L2 & 0.21 & 0.87 & 3.01 & 22.30 & 0.48 & 0.32 & 0.71 & 0.10 & 6.20 & 69.36 & 103.30 \\
\hline SVT1 L1 & 0.57 & 2.36 & 4.89 & 19.07 & 0.23 & 1.31 & 2.01 & 0.11 & 9.86 & 70.96 & 111.37 \\
\hline SVT1 L2 & 0.62 & 2.21 & 5.76 & 23.79 & 0.88 & 1.23 & 2.93 & 0.22 & 3.67 & 65.63 & 106.94 \\
\hline SVT1 L3 & 0.68 & 2.09 & 5.34 & 18.71 & 0.18 & 1.01 & 1.79 & 0.12 & 5.23 & 76.05 & 111.20 \\
\hline SVT1 L3 & 0.71 & 2.33 & 4.98 & 18.02 & 0.24 & 0.62 & 1.34 & 0.09 & 4.54 & 80.19 & 113.06 \\
\hline \multicolumn{12}{|c|}{ Smithing slag/Crown material } \\
\hline SVT2 L2 & 0.44 & 1.84 & 5.27 & 20.60 & 0.11 & 0.86 & 2.22 & 0.15 & 7.00 & 71.96 & 109.90 \\
\hline SVT2 L3 & 0.28 & 0.84 & 7.26 & 16.30 & 0.35 & 0.49 & 0.14 & 0.06 & 3.90 & 76.44 & 106.06 \\
\hline SVT31 L3 & 0.73 & 2.18 & 8.16 & 17.50 & 0.21 & 0.65 & 1.47 & 0.09 & 4.80 & 70.63 & 106.42 \\
\hline SVT4 L2 & 0.47 & 2.56 & 6.67 & 19.80 & 0.61 & 0.73 & 0.93 & 0.15 & 4.10 & 68.23 & 104.25 \\
\hline SVT1L4 & 0.24 & 1.87 & 1.48 & 11.30 & 0.45 & 0.18 & 0.19 & 0.02 & 6.50 & 79.29 & 101.30 \\
\hline SVT2 L2 & 0.68 & 1.80 & 4.21 & 21.80 & 0.13 & 0.91 & 1.43 & 0.13 & 6.20 & 69.82 & 106.40 \\
\hline SVT3 L1 & 0.23 & 1.93 & 2.38 & 11.40 & 0.07 & 0.21 & 0.22 & 0.05 & 5.70 & 84.70 & 106.60 \\
\hline \multicolumn{12}{|c|}{ Undiagnostic Slag } \\
\hline SVT1 L2 & 0.64 & 2.08 & 6.13 & 24.30 & 0.90 & 1.47 & 3.01 & 0.21 & 6.71 & 59.67 & 105.12 \\
\hline SVT1 L3 & 0.76 & 2.28 & 6.06 & 22.50 & 0.81 & 1.67 & 2.04 & 0.18 & 5.31 & 69.20 & 110.81 \\
\hline SVT1 L1 & 0.70 & 1.66 & 4.84 & 17.30 & 0.20 & 0.61 & 1.53 & 0.13 & 10.00 & 65.23 & 102.20 \\
\hline \multicolumn{12}{|l|}{ Furnace Wall } \\
\hline SVT1 L4 & 1.24 & 0.89 & 22.80 & 55.80 & 0.25 & 1.37 & 0.92 & 0.52 & 0.00 & 4.75 & 87.26 \\
\hline SVT1 L3 & 2.35 & 1.78 & 22.40 & 58.00 & 0.29 & 1.52 & 0.22 & 0.53 & 0.10 & 5.18 & 89.92 \\
\hline SVT2 L3 & 2.43 & 1.26 & 20.20 & 68.40 & 0.13 & 2.06 & 0.77 & 0.72 & 0.10 & 5.58 & 101.65 \\
\hline \multicolumn{12}{|l|}{ Tuyeres } \\
\hline SVT1 L3 & 0.91 & 2.07 & 18.80 & 44.40 & 2.64 & 0.91 & 3.15 & 1.33 & 0.20 & 15.34 & 88.78 \\
\hline SVT2 L3 & 1.55 & 0.62 & 21.70 & 58.40 & 0.11 & 1.23 & 0.98 & 0.49 & 0.00 & 4.76 & 88.35 \\
\hline SVT2 L4 & 1.19 & 0.62 & 22.50 & 55.50 & 0.12 & 1.26 & 0.92 & 0.52 & 0.00 & 4.87 & 86.36 \\
\hline \multicolumn{12}{|l|}{ Ores } \\
\hline SVT2 L3 & 0.45 & 1.21 & 2.21 & 4.16 & 0.08 & 0.79 & 0.30 & 0.86 & 8.23 & 81.23 & 99.52 \\
\hline SVT2 L3 & 0.56 & 1.03 & 1.53 & 3.67 & 0.09 & 1.20 & 0.25 & 0.99 & 10.56 & 78.13 & 98.01 \\
\hline
\end{tabular}




\begin{tabular}{|c|c|c|c|c|c|c|c|c|c|c|c|}
\hline BARANDA & $\mathrm{Na}_{2} \mathrm{O}$ & MgO & $\mathrm{Al}_{2} \mathbf{O 3}$ & $\mathrm{SiO}_{2}$ & $\mathbf{P}_{2} \mathbf{O}_{5}$ & $\mathbf{K}_{\mathbf{2}} \mathbf{O}$ & $\mathrm{CaO}$ & $\mathrm{TiO}_{2}$ & MnO & FeO & Total \\
\hline \multicolumn{12}{|l|}{ Tap Slag } \\
\hline BNT3 L4 & 0.61 & 2.18 & 6.16 & 25.20 & 0.82 & 1.48 & 3.06 & 0.23 & 2.30 & 62.84 & 104.90 \\
\hline BNT1 L2 & 0.35 & 0.77 & 7.63 & 19.90 & 0.38 & 0.61 & 0.75 & 0.13 & 6.80 & 63.76 & 101.08 \\
\hline BNT2 L1 & 0.51 & 1.96 & 8.32 & 28.45 & 0.51 & 0.85 & 2.16 & 0.19 & 2.76 & 65.89 & 111.60 \\
\hline BNT3 L4 & 0.65 & 1.30 & 7.39 & 24.40 & 0.61 & 1.00 & 1.19 & 0.18 & 6.27 & 66.07 & 109.05 \\
\hline BNT3 L1 & 0.61 & 0.67 & 3.94 & 19.45 & 0.62 & 1.13 & 0.29 & 0.06 & 4.41 & 76.97 & 108.14 \\
\hline BNT1 L2 & 0.20 & 0.76 & 4.87 & 24.98 & 0.05 & 0.56 & 0.61 & 0.13 & 6.85 & 67.06 & 106.07 \\
\hline \multicolumn{12}{|c|}{ Furnace Slag } \\
\hline BNT1L2 & 0.15 & 0.84 & 2.95 & 22.70 & 0.07 & 0.39 & 0.83 & 0.17 & 6.30 & 68.18 & 102.60 \\
\hline BNT2 L3 & 0.36 & 1.99 & 5.16 & 20.60 & 0.34 & 0.88 & 2.21 & 0.15 & 7.00 & 72.31 & 111.00 \\
\hline BNT2 L2 & 0.58 & 2.03 & 6.16 & 25.31 & 0.81 & 1.47 & 3.08 & 0.23 & 2.33 & 70.25 & 112.26 \\
\hline BNT1L1 & 0.06 & 0.82 & 3.42 & 12.92 & 0.30 & 0.61 & 0.74 & 0.14 & 6.41 & 78.48 & 103.90 \\
\hline BNT1L2 & 0.15 & 0.84 & 2.91 & 22.71 & 0.08 & 0.40 & 0.83 & 0.11 & 6.33 & 75.76 & 110.11 \\
\hline BNT2 L3 & 0.36 & 1.99 & 5.17 & 20.60 & 0.12 & 0.88 & 2.22 & 0.15 & 7.03 & 80.35 & 118.88 \\
\hline BNT3 L1 & 0.55 & 0.69 & 3.80 & 18.97 & 0.60 & 1.10 & 0.33 & 0.04 & 4.88 & 79.02 & 109.98 \\
\hline BNT3 L2 & 0.63 & 1.03 & 5.77 & 25.54 & 0.50 & 1.46 & 1.43 & 0.09 & 3.94 & 75.93 & 116.32 \\
\hline \multicolumn{12}{|c|}{ Smithing slag } \\
\hline BNT1 L3 & 0.51 & 0.79 & 3.28 & 13.70 & 0.08 & 0.64 & 0.39 & 0.04 & 7.40 & 73.29 & 100.10 \\
\hline BNT1L1 & 0.11 & 0.75 & 3.49 & 13.00 & 0.32 & 0.62 & 0.74 & 0.13 & 6.40 & 81.16 & 106.72 \\
\hline BNT1 L1 & 0.37 & 0.91 & 3.17 & 13.44 & 0.07 & 0.65 & 0.32 & 0.06 & 6.93 & 90.06 & 115.98 \\
\hline BNT3 L4 & 0.06 & 1.80 & 2.60 & 11.63 & 0.10 & 0.22 & 0.24 & 0.05 & 6.06 & 94.94 & 117.71 \\
\hline BNT3 L4 & 0.09 & 1.76 & 3.03 & 12.56 & 0.07 & 0.21 & 0.19 & 0.05 & 5.81 & 96.13 & 119.90 \\
\hline BNT1 L1 & 0.25 & 0.88 & 4.53 & 16.13 & 0.04 & 0.51 & 0.36 & 0.06 & 7.02 & 87.34 & 117.12 \\
\hline \multicolumn{12}{|c|}{ Undiagnostic slag } \\
\hline BNT3 L3 & 0.78 & 1.48 & 6.53 & 21.00 & 0.62 & 0.91 & 0.84 & 0.13 & 6.80 & 62.69 & 101.80 \\
\hline BNT3L4 & 0.54 & 1.36 & 7.46 & 24.40 & 0.61 & 0.99 & 1.17 & 0.18 & 6.20 & 59.27 & 102.20 \\
\hline BNT3 L3 & 0.82 & 1.04 & 6.13 & 20.40 & 0.83 & 0.89 & 0.75 & 0.12 & 6.00 & 67.55 & 104.53 \\
\hline \multicolumn{12}{|c|}{ Furnace Wall } \\
\hline BNT2 L2 & 1.39 & 0.83 & 16.50 & 72.00 & 0.01 & 2.29 & 1.38 & 0.63 & 0.00 & 4.40 & 99.52 \\
\hline BNT3 L4 & 0.69 & 0.98 & 18.30 & 63.60 & 0.46 & 3.83 & 4.68 & 0.39 & 0.00 & 4.02 & 96.95 \\
\hline BNT2L2 & 0.95 & 0.39 & 18.40 & 61.40 & 3.72 & 4.79 & 1.11 & 0.28 & 0.00 & 2.05 & 93.02 \\
\hline \multicolumn{12}{|l|}{ Tuyeres } \\
\hline BNT3 L2 & 0.91 & 0.27 & 24.20 & 60.30 & 3.03 & 2.43 & 0.67 & 0.25 & 0.00 & 2.56 & 94.62 \\
\hline BNT1L2 & 1.57 & 0.26 & 17.90 & 64.10 & 5.03 & 5.75 & 1.01 & 0.82 & 0.00 & 1.12 & 97.55 \\
\hline BNT 1L3 & 1.59 & 1.69 & 23.60 & 53.10 & 3.99 & 1.88 & 1.62 & 0.71 & 0.00 & 5.82 & 94.00 \\
\hline \multicolumn{12}{|l|}{ Ores } \\
\hline BNT1 L3 & 0.20 & 1.56 & 2.86 & 6.43 & 0.05 & 0.06 & 0.86 & 0.79 & 8.97 & 75.27 & 97.05 \\
\hline BNT3 L3 & 0.60 & 0.98 & 3.13 & 5.12 & 0.06 & 0.06 & 0.92 & 0.67 & 7.92 & 78.13 & 97.59 \\
\hline
\end{tabular}

